\title{
Healthy Stem Cell Donor
}

National Cancer Institute

\section{Source}

National Cancer Institute. Healthy Stem Cell Donor. NCI Thesaurus. Code C115223.

Indicates that a donor of stem cells is healthy. 